\title{
Pengaruh Model Problem Based Learning Berbasis Portofolio Terhadap Kompetensi Pengetahuan Matematika
}

\author{
I Gede Beny Darsana ${ }^{1 *}$, I Wayan Wiarta², Made Putra ${ }^{3}$ \\ 123 Jurusan Pendidikan Guru Sekolah Dasar, Universitas Pendidikan Ganesha
}

\begin{abstract}
Abstrak
Penelitian ini bertujuan untuk mengetahui pengaruh model problem based learning berbasis portofolio terhadap kompetensi pengetahuan matematika siswa kelas IV sekolah dasar gugus I Gusti Ngurah Rai tahun pelajaran 2017/2018. Jenis penelitian ini adalah penelitian eksperimen semu dengan menggunakan desain penelitian nonequilvalent control group design. Populasi penelitian ini adalah seluruh siswa kelas IV SD Gugus I Gusti Ngurah Rai tahun pelajaran 2017/2018 sebanyak 249 siswa. Sampel penelitian ditentukan dengan teknik random sampling. Sampel dalam penelitian ini adalah kelas IVB SDN 4 Sanur sebagai kelompok eksperimen dan kelas IV SDN 1 Sanur sebagai kelompok kontrol yang berjumlah 60 siswa. Data kompetensi pengetahuan matematika diperoleh dengan instrumen berupa tes pilihan ganda biasa. Selanjutnya data dianalisis dengan uji-t. Hasil analisis menunjukkkan bahwa terdapat pengaruh yang signifikan kompetensi pengetahuan matematika antara kelompok siswa yang dibelajarkan mengggunakan model problem based learning berbasis portofolio dan yang dibelajarkan menggunakan pembelajaran konvensional dengan pendekatan saintifik pada siswa kelas IV SD Gugus I Gusti Ngurah Rai tahun pelajaran $2017 / 2018$. Hal tersebut dibuktikan dengan hasil $t_{\text {hitung }}=2,406$ dan $t_{\text {tabel }}=2,000$ pada taraf signifikansi $5 \%$ dengan $d k=n 1+n 2-2=(30+30-2)=58$. Demikian pula nilai rata-rata kompetensi pengetahuan matematika siswa kelompok eksperimen $\bar{X}=$ $78,50>\bar{X}=74,17$ rata-rata kompetensi pengetahuan matematika siswa kelompok kontrol. Dengan demikian dapat disimpulkan bahwa terdapat pengaruh model Problem Based Learning berbasis portofolio terhadap kompetensi pengetahuan matematika siswa kelas IV sekolah dasar gugus I Gusti Ngurah Rai Tahun Pelajaran $2017 / 2018$.
\end{abstract}

\section{Keywords:}

Problem Based

Learning, portofolio,

kompetensi

pengetahuan

matematika.

\section{PENDAHULUAN}

Pendidikan merupakan hal yang sangat penting di dalam suatu Negara. Suatu Negara dikatakan maju dilihat dari segi pendidikan. Selain itu Pendidikan merupakan sarana penting untuk menciptakan Sumber Daya Manusia yang berkualitas dan berkompeten. Maka dari itu sangat penting bagi suatu Negara untuk memberikan pendidikan yang berkualitas dan bermutu kepada warga negaranya. Pendidikan adalah usaha sadar untuk menyiapkan peserta didik melalui kegiatan bimbingan, pengajaran, dan/atau latihan bagi peranannya di masa yang akan datang. Dalam penyelenggaraan pendidikan di Indonesia sendiri ditetapkan jenjang-jenjang pendidikan bagi siswa di antaranya adalah pendidikan anak usia dini, pendidikan anak sekolah dasar, pendidikan sekolah menengah pertama, pendidikan sekolah menengah atas hingga perguruan tinggi. Dari beberapa jenjang pendidikan tersebut, salah satu jenjang yang memegang peranan penting adalah pendidikan anak sekolah dasar. Maka dari itu dalam pendidikan anak sekolah dasar perlu diperhatikan kegiatan pembelajaran yang digunakan. Pada pelaksanakan pendidikan perlu adanya suatu kurikulum yang dapat mendukung proses pendidikan yang baik.

Pendidikan lebih dari sekedar pengajaran, yang dapat dikatakan sebagai suatu proses transfer ilmu, transformasi nilai, dan pembentukan kepribadian dengan segala aspek yang dicakupnya. Dengan demikian pengajaran lebih berorientasi pada pembentukan spesialis atau bidangbidang tertentu, oleh karena itu perhatian dan minatnya lebih bersifat teknis. Pendidikan merupakan suatu proses yang diperlukan untuk mendapatkan keseimbangan dan kesempurnaan dalam perkembangan individu 
maupun masyarakat. Penekanan pendidikan dibanding dengan pengajaran terletak pada pembentukan kesadaran dan kepribadian individu atau masyarakat di samping transfer ilmu dan keahlian (Nurkholis, 2013).

Dengan proses semacam ini suatu bangsa atau negara dapat mewariskan nilai-nilai keagamaan, kebudayaan, pemikiran dan keahlian kepada generasi berikutnya, sehingga mereka betul-betul siap menyongsong masa depan kehidupan bangsa dan negara yang lebih cerah. Pendidikan juga merupakan sebuah aktifitas yang memiliki maksud atau tujuan tertentu yang diarahkan untuk mengembangkan potensi yang dimiliki manusia baik sebagai manusia ataupun sebagai masyarakat dengan sepenuhnya.

Sesuai dengan UU Sisdiknas kurikulum adalah seperangkat rencana dan pengaturan mengenai tujuan, isi, dan bahan pelajaran serta cara yang digunakan sebagai pedoman penyelenggaraan kegiatan pembelajaran untuk mencapai tujuan pendidikan tertentu. Peranan dan fungsi kurikulum menyesuaikan dengan keberadaan manusia yang selalu menghadapi perubahan. Perubahan kurikulum KTSP menjadi Kurikulum 2013 di Indonesia bertujuan untuk mempersiapkan manusia Indonesia agar memiliki kemampuan hidup sebagai pribadi dan warga negara yang beriman, produktif, kreatif, inovatif, dan afektif serta mampu berkontribusi pada kehidupan bermasyarakat, berbangsa, dan bernegara (Permendikbud no 57 tahun 2014 lampiran I). Penerapan kurikulum 2013 dilapangan masih membuat siswa secara pasif menyerap struktur yang diberikan oleh guru yang terdapat di buku pelajaran. Dalam kurikulum 2013 siswa dituntut melalui beberapa proses secara aktif mencari, mengolah, mengkonstruksi, dan menerapkan pengetahuan. Dari berbagai muatan materi di sekolah dasar, Matematika merupakan salah satu muatan materi yang sering muncul dalam pembelajaran karena berhubungan dengan berbagai aktivitas kehidupan dan masalah sehari-hari.

Pasal 1 UU SISDIKNAS no. 20 tahun 2003 disebutkan bahwa Sistem Pendidikan Nasional adalah keseluruhan komponen pendidikan yang saling terkait secara terpadu untuk mencapai tujuan pendidikan nasional. Berangkat dari bunyi pasal ini dapat diketahui bahwa pendidikan adalah sistem yang merupakan suatu totalitas struktur yang terdiri dari komponen yang saling terkait dan secara bersama menuju kepada tercapainya tujuan (Soetarno, 2003: 2). Adapun komponen-komponen dalam pendidikan nasional antara lain adalah lingkungan, sarana-prasarana, sumberdaya, dan masyarakat. Komponenkomponen tersebut bekerja secara bersama-sama, saling terkait dan mendukung dalam mencapai tujuan pendidikan (Munirah, 2015).

Menurut (Susanto, 2014:185) "Matematika merupakan salah satu disiplin ilmu yang dapat meningkatkan kemampuan berpikir dan berargumentasi, memberikan konstribusi dalam penyelesaian masalah sehari-hari dan dalam dunia kerja, serta memberikan dukungan dalam pengembangan ilmu pengetahuan dan teknologi". Kebutuhan akan aplikasi matematika saat ini dan masa depan tidak hanya untuk keperluan sehari-hari, tetapi terutama dalam dunia kerja, dan untuk mendukung perkembangan ilmu pengetahuan. Oleh karena itu matematika sebagai ilmu dasar perlu dikuasai dengan baik oleh siswa, terutama sejak usia SD.

Mengingat begitu pentingnya semua mata pelajaran, salah satunya adalah pembelajaran Matematika. Pembelajaran Matematika seyogianya disajikan dengan cara yang menarik, dengan menggunakan permasalahan riil sebagai suatu konteks bagi siswa untuk berpikir kritis, sehingga siswa merasa tertarik dan melibatkan diri secara aktif dalam proses belajar mengajar sehubungan dengan tujuan pembelajaran tersebut. Namun, pembelajaran dengan menyajikan permasalahan riil sebagai suatu konteks bagi siswa untuk berpikir kritis masih jarang digunakan terutama untuk siswa yang duduk di bangku sekolah dasar. Kegiatan pembelajaran yang sering dilakukan kepada siswa di kelas masih menggunakan kombinasi beberapa metode pembelajaran, seperti metode ceramah, metode Tanya jawab, dan metode penugasan.

Matematika merupakan ilmu universal yang mendasari perkembangan teknologi modern saat ini. Mengapa demikian?, karena matematika memiliki peran penting yang menjadi sarana dalam pemecahan masalah kehidupan (Misel, 2016) (Dewimarni, 2017). Pentingnya matematika dalam pembelajaran mulai dari jenjang sekolah dasar sampai perguruan tinnggi yang berfungsi dalam mengembangkan daya nalar kemampuan berpikir 16 (Afifah, 2012; Rasyid, 2017; Somawati, 2018). Konsep-konsep dalam matematika yang abstrak tersusun berjenjang dan berurutan masih diperlukan pembuktian-pembuktian khusus, sehingga dalam mempelajari matematika konsep sebelumnya harus dikuasai karena merupakan prasyarat untuk melanjutkan konsep berikutnya (Misel, 2016) (Suandito, 2017).

Susanto (2014:191) menyatakan bahwa, proses pembelajaran matematika di di sekolah dasar masih belum menunjukkan hasil yang memuaskan, dilihat dari hasil ujian akhir sekolah (UAS) rata-rata hasil kompetensi pengetahuan matematika untuk siswa sekolah dasar berkisar antara nilai 5 dan 6, bahkan lebih kecil dari angka ini. Hal ini diperkuat oleh hasil observasi yang telah dilaksanakan pada tanggal 22 Januari 2018 dengan wali kelas IV di masing-masing sekolah dasar yang berada di Gugus I Gusti Ngurah Rai Tahun Pelajaran 2017/2018 diperoleh dari nilai raport semester 1 pada pelajaran 
matematika yaitu dari 249 siswa kelas IV, 5 siswa mendapat nilai A, 37 siswa mendapat nilai B, 169 siswa mendapat nilai C, 38 siswa mendapat nilai D. Berdasarkan data yang diperoleh, 42 siswa atau 16,86\% yang sudah mencapai nilai yang diharapkan. Sedangkan 207 siswa atau 83,13\% yang belum mampu menunjukkan hasil belajar yang baik atau belum memperoleh predikat B.

Mencermati permasalahan tersebut, perlu dilakukan variasi model pembelajaran dengan menggunakan permasalahan riil sebagai suatu konteks bagi siswa untuk berpikir kritis agar siswa merasa tertarik dan melibatkan diri secara aktif dalam pembelajaran. Salah satu model pembelajaran yang menggunakan permasalahan riil sebagai suatu konteks bagi siswa untuk berpikir kritis adalah model Problem Based Learning berbasis portofolio.

Model Problem Based Learning merupakan pembelajaran yang penyampaiannya dilakukan dengan cara menyajikan suatu permasalahan, mengajukan pertanyaan-pertanyaan, memfasilitasi penyelidikan, dan membuka dialog (Sani, 2015:127). Model pembelajaran Problem Based Learning dapat membuat siswa belajar melalui upaya permasalahan riil secara terstruktur untuk mengkonstruksi pengetahuan siswa. Pembelajaran ini menuntut siswa aktif melakukan penyelidikan dalam menyelesaikan permasalahan dan guru berperan sebagai fasilitator atau pembimbing.

Selain menggunakan model Problem Based Learning untuk meningkatkan penguasaan kompetensi belajar pengetahuan matematika siswa, perlunya upaya untuk mengintegrasikan kegiatan pengukuran hasil belajar siswa dengan keseluruhan proses pembelajaran dengan menggunakan portofolio. Portofolio sebagai dokumen untuk menyimpan hasil belajarnya. Muslich (2011:88) menyatakan "Portofolio merupakan kumpulan karya (hasil kerja) seorang siswa dalam periode tertentu”. Sejalan dengan Riadi (2013) "portofolio adalah suatu kumpulan pekerjaan siswa dengan maksud tertentu dan terpadu yang diseleksi menurut paduan - panduan yang ditentukan". Sanjaya (2009:363) menyatakan, Portofolio dapat diartikan sebagai kumpulan karya siswa yang disusun secara sistematis dan terorganisir sebagai hasil dari usaha pemblajaran yang telah dilakukannya dalam kurun waktu tertentu. Melalui portofolio guru dapat mengetahui peningkatan - peningkatan Kompetensi Pengetahuan Matematika. Hal ini bertujuan agar guru bisa mendokumentasikan dan menilai hasil pekerjaan siswa sehingga bisa memantau kemajuan siswa dari hari ke hari dan mendorong siswa merefleksi pembelajaran mereka sendiri. Dengan demikian siswa bisa memperbaiki hasil belajarnya.

Berdasarkan pemaparan tersebut, maka dilakukan penelitian yang berjudul Pengaruh Model Problem Based Learning Berbasis Portofolio Terhadap Kompetensi Pengetahuan Matematika Siswa Kelas IV SD Gugus I Gusti Ngurah Rai Tahun Pelajaran 2017/2018.

\section{METODE PENELITIAN}

Penelitian dilaksanakan di kelas IV SD Gugus I Gusti Ngurah Rai. Waktu pelaksanaan penelitian dilaksanakan dari bulan April sampai dengan bulan Mei 2018, di dua sekolah dasar di Gugus I Gusti Ngurah Rai yang merupakan sampel dalam penelitian yaitu SDN 4 Sanur sebagai kelompok eksperimen dan SDN 1 Sanur sebagai kelompok kontrol. Pelaksanaan penelitian pada kelompok eksperimen dan kelompok kontrol terdiri atas pemberian pre test pada kelompok eksperimen dan kelompok kontrol, memberikan perlakuan sebanyak 6 kali pada kelompok eksperimen dan kelompok kontrol serta pemberian post test pada kelompok eksperimen dan kelompok kontrol.

Jenis penelitian yang diguna-kan adalah eksperimen semu (quasi experiment). Penelitian eksperimen semu ini membandingkan dua jenis pembelajaran model problem based learning berbasis portofolio dan pembelajaran konvensional yang mana kedua pembelajaran tersebut mempunyai pengaruh terhadap satu variabel terikat (Kompetensi). Hal ini dikarenakan kemampuan peneliti da-lam mengamati perilaku siswa sangat terbatas terutama ketika siswa ber-ada di luar sekolah (rumah), peneliti juga tidak memiliki kemampuan untuk mengetahui persepsi siswa terhadap perlakuan secara pasti. Desain eksperimen yang digunakan adalah "nonequivalent control group design". Pada desain ini kedua kelompok yang akan diteliti diberikan pre test dan post test. Pre test tidak dianalisis tetapi hanya digunakan untuk penyetaraan kelompok. Teknik yang digunakan dalam peyetaraan kelompok adalah dengan menggunakan teknik matching. Setelah itu peneliti memberikan perlakuan, yaitu dengan menerapkan model problem based learning kepada kelompok eksperimen, dan pembelajaran konvensional pada kelas kontrol.

Populasi penelitian ini adalah seluruh siswa kelas IV SD Gugus I Gusti Ngurah Rai tahun pelajaran 2017/2018 yang berjumlah 249 siswa. Sampel adalah bagian dari jumlah dan karakteristik yang dimiliki oleh populasi (Sugiyono, 2016:118). Teknik pengambilan sampel pada penelitian ini dilakukan dengan cara teknik random sampling, karena dalam penelitian ini dipilih 2 kelas yang dijadikan subjek penelitian. Terdapat sebanyak 7 kelas IV yang terdiri dari 5 SD di Gugus I Gusti Ngurah Rai. Setelah mendapatkan 2 kelas yang diperoleh dari hasil random sampel kelompok, maka selanjutnya 2 kelas yang terpilih 
diberikan pre test. Pre test yang diberikan untuk menyetarakan kelompok. Penyetaraan kelompok dilakukan dengan teknik matching. Setelah didapatkan pasangan de-ngan nilai yang sama maka 2 kelas tersebut dikatakan setara. Berdasarkan hasil penyetaraan yang telah dilakukan terdapat 30 pasang siswa yang memiliki nilai yang sama, yaitu 30 siswa dari Kelas IVB SDN 4 Sanur dan 30 siswa dari kelas IV SDN 1 Sanur. Selanjutnya dilakukan pengundian untuk menentukan kelas kontrol dan kelas eksperimen. Sehingga populasi sampel yang digunakan dalam penelitian ini berjumlah 60 siswa, yaitu 30 siswa dari SDN 4 Sanur sebagai kelompok eksperimen dengan diberiperlakuan berupa model problem based learning berbasis portofolio dan 30 siswa dari SDN 1 Sanur sebagai kelompok kontrol dengan diberi perlakuan berupa pembelajaran konvensional.

Data yang dikumpulkan dalam penelitian ini adalah data kompetensi pengetahuan matematika siswa kelas IV SD Gugus I Gusti Ngurah Rai Tahun Pelajaran 2017/2018. Teknik pengumpulan data ada dua yaitu dengan teknik tes dan teknik non tes, namun dalam penelitian ini, metode pengumpulan data yang digunakan adalah metode tes. Kegiatan pengumpulan data dilaksanakan pada siswa kelas IV SD di SD Gugus I Gusti Ngurah Rai Tahun Pelajaran 2017/2018 yang menjadi anggota sampel. Data tentang kompetensi pengetahuan matematika dikumpulkan dengan tes kompetensi pengetahuan matematika. Tes yang akan digunakan untuk mengukur kompetensi pengetahuan matematika berupa tes objektif dalam bentuk pilihan ganda biasa. Rancangan penelitian yang digunakan dalam penelitian ini adalah kuantitatif dengan menggunakan uji-t sebagai alat untuk menganalisis data. Deskripsi data hasil kompetesnsi pengetahuan matematika siswa yang dipaparkan meliputi nilai mean, varians, dan standar deviasi.

\section{ANALISIS DAN PEMBAHASAN}

Kelas IVB SDN 4 Sanur ditetapkan sebagai kelompok eksperimen yang diberi perlakuan berupa pengaruh model problem based learning berbasis penilaian portofolio sebanyak 6 kali pertemuan, selanjutnya diberikan post test untuk memeroleh hasil kompetensi pengetahuan matematika. Nilai mean atau rerata kom-petensi pengetahuan matematika siswa yang mengikuti pembelajaran menggunakan model problem based learning berbasis portofolio, yaitu $\bar{X}=78,50$ dengan varians 35,78 dan standar deviasi $(s=5,98)$, sedangkan nilai mean atau rerata kompetensi pengetahuan matematika siswa yang mengikuti pembelajaran konvensional, yaitu $\bar{X}=74,17$ dengan varians 61,11 dan standar deviasi $(s=7,82)$. Perhitungan analisis data hasil penelitian yang diperoleh menunjukkan bahwa kompetensi pengetahuan matematika kelompok eksperimen yakni siswa yang mengikuti pembelajaran menggunakan model problem based learning berbasis portofolio memiliki nilai mean lebih tinggi daripada kelompok kontrol yakni siswa yang mengikuti pembelajaran menggunakan pembelajaran konvensional yaitu $\bar{X}=$ $78,50>\bar{X}=74,17$. Uji prasyarat dilakukan terlebih dahulu sebelum uji hipotesis menggunakan uji-t. Uji prasyarat ter-sebut meliputi uji normalitas dan uji homogenitas varians diuraikan berikut ini.

Uji normalitas dilakukan untuk mengetahui sebaran frekuensi skor, untuk menguji data kompetensi pengetahuan matematika kelompok eksperimen dan kontrol adalah rumus Chi Kuadrat. Kriteria pengujian pada uji normalitas adalah jika $\mathrm{x}^{2}$ hitung $\leq \mathrm{x}^{2}$ tabel maka sebaran data kedua kelompok berdistribusi normal. Berdasarkan hasil uji normalitas kelompok eksperimen, diperoleh Chi Kuadrat hitung $\left(\mathrm{x}^{2}\right.$ hitung $\left.=7,55\right)$ kemudian nilai tersebut dibandingkan dengan Chi Kuadrat tabel dengan taraf signifikan $5 \%$ dk $5\left(x^{2}\right.$ tabel= 11,070). Hal ini menunjukkan bahwa $x^{2}$ hitung $\leq \mathrm{x}^{2}$ tabel berarti data hasil kompetensi pengetahuan matematika kelompok eksperimen berdistribusi normal. Berdasarkan hasil uji normalitas kelompok kontrol, diperoleh Chi Kuadrat hitung $\left(\mathrm{x}^{2}\right.$ hitung $\left.=5,50\right)$ kemudian nilai tersebut dibandingkan dengan Chi Kuadrat tabel $\left(x^{2}\right.$ tabel= 11,070). Hal ini menunjukkan bahwa $x^{2}$ hitung $\leq x^{2}$ tabel berarti data hasil kompetensi penge-tahuan matematika kelompok kontrol berdistribusi normal.

Pengujian homogenitas varians antar kelompok dimaksudkan untuk meyakinkan bahwa perbedaan yang diperoleh uji-t benar-benar berasal dari perbedaan antar kelompok bukan disebabkan oleh perbedaan di dalam kelompok. Uji homogenitas varians yang dilakukan dalam pene-litian ini menggunakan uji F. Dari hasil analisis, diperoleh $\mathrm{F}_{\text {hitung }}=1,71$ dan $\mathrm{F}_{\text {tabel }}=1,84$. Hal ini berarti $\mathrm{F}_{\text {hitung }} \leq \mathrm{F}_{\text {tabel }}$, sehingga data kedua kelompok memiliki varians yang homogen. Berdasarkan hasil uji prasyarat yang terdiri dari uji normalitas dan uji homogenitas varians, disimpulkan bahwa data kedua kelompok sampel ialah berdistribusi normal dan memiliki varians yang homogen. Dengan demikian, uji hipotesis menggunakan uji-t dapat dilakukan.

Hipotesis yang diuji dalam pe-nelitian ini adalah tidak terdapat perbedaan yang signifikan kompe-tensi pengetahuan matematika antara siswa kelas IV SD Gugus I Gusti Ngurah Rai tahun pelajaran 2017/2018 yang dibelajarkan menggunakan model problem based learning berbasis portofolio dan yang dibelajarkan menggunakan pembelajaran konvensional. Hasil uji prasyarat yang me-liputi uji normalitas 
dan homogenitas varians yang dilakukan dalam pe-nelitian ini diperoleh kedua kelom-pok sampel berdistribusi normal dan memiliki varians yang homogen. Analisis statistik yang digunakan un-tuk menguji hipotesis penelitian ini adalah uji-t dengan separated varians. Berdasarkan hasil perhi-tungan uji-t, diperoleh $t_{\text {hitung }}=2,406$ dan untuk taraf signifikansi $5 \%$ dengan $\mathrm{dk}=(30+30-2)=58$ diperoleh $\mathrm{t}_{\text {tabel }}=$ 2,000. Dengan demikian, nilai thitung $>$ ttabel yakni 2,406 $>2,000$ sehingga $\mathrm{H}_{0}$ ditolak.

Berdasarkan uji hipotesis diperoleh thitnung $=2,406$ sedangkan pada taraf signifikansi $5 \%$ dan $\mathrm{dk}=$ 58 diperoleh nilai $t_{\text {tabel }}=2,000$ sehingga $t_{\text {hitnung }}=2,406>t_{\text {tabel }}=2,000$. Dengan demikian, hipotesis nol $\mathrm{H}_{0} \mathrm{di}$ tolak yang menyatakan bahwa tidak terdapat perbedaan yang signifikan kompetensi pengetahuan matematika kelompok siswa yang dibelajarkan melalui model problem based learning berbasis portofolio dengan kelompok siswa yang dibelajarkan melalui pembelajaran konvensional pada kelas IV sekolah dasar Gugus I Gusti Ngurah Rai tahun pelajaran 2017/2018 dan $\mathrm{H}_{a}$ diterima yang menyatakan bahwa terdapat perbedaan yang signifikan kompetensi pengetahuan matematika kelompok siswa yang dibelajarkan melalui model problem based learning berbasis portofolio dengan kelompok siswa yang dibelajarkan melalui pembelajaran konvensional pada kelas IV sekolah dasar Gugus I Gusti Ngurah Rai tahun pelajaran 2017/2018. Hal ini berarti terdapat pengaruh model problem based learning berbasis portofolio terhadap kompetensi pengetahuan matematika siswa kelas IV SD Gugus I Gusti Ngurah Rai tahun pelajaran 2017/2018.

Perolehan hasil perhitungan analisis data yang dilakukan menunjukkan bahwa nilai rerata siswa yang dibelajarkan problem based learning berbasis portofolio ( $\bar{X}=78,50$ ) dengan perolehan nilai terendah 69,6 dan nilai tertinggi 91,3, sesuai dengan analisis nilai kompetensi pengetahuan matematika siswa pada kelompok eksperimen. Hasil rata-rata siswa yang dibelajarkan menggunakan pembelajaran konvensional ( $\bar{X}=74,17$ ) dengan perolehan nilai terendah 56,5 dan nilai tertinggi 91,3 , sesuai dengan analisis nilai kompetensi pengetahuan matematika siswa pada kelompok kontrol.

Hasil perolehan rata-rata kelompok eksperimen dan kelompok kontrol memiliki perbedaan sebesar 4,3. Dengan demikian, terdapat pengaruh kompetensi pengetahuan matematika antara siswa kelas IV di SD Gugus I Gusti Ngurah Rai tahun pelajaran 2017/2018 yang dibelajarkan menggunakan model problem based learning berbasis portofolio dan siswa yang dibelajarkan menggunakan pembelajaran konvensional.

Berdasarkan hasil analisis data, dapat dinyatakan kedua kelompok sampel penelitian yang memiliki kemampuan setara, setelah diberikan perlakuan berupa model problem based learning berbasis portofolio dan yang dibelajarkan menggunakan pembelajaran konvensional diperoleh hasil kompetensi pengetahuan matematika yang berbeda. Hal ini dapat dilihat juga dari $\bar{X}$ siswa yang mengikuti pembelajaran menggunakan model problem based learning berbasis portofolio lebih tinggi dibandingkan dengan $\bar{X}$ siswa yang mengikuti pembelajaran konvensional. Perbedaan hasil kompetensi pengetahuan dengan perolehan nilai rerata yang lebih tinggi pada kelompok eksperimen dibandingkan kelompok kontrol disebabkan oleh perlakuan berupa model problem based learning berbasis portofolio dalam kompetensi pengetahuan matematika diberikan pada kelompok eksperimen.

Pada kelompok eksperimen, kegiatan pembelajaran dalam muatan Matematika menggunakan model Problem Based Learning berbasis portofolio berjalan dengan optimal dan kondusif. Pembelajaran dengan model Problem Based Learning berbasis portofolio secara tidak langsung telah menumbuhkan minat belajar siswa yang masih sangat kurang saat ini. Model Problem Based Learning berbasis portofolio akan membuat siswa lebih aktif dan kreatif dalam pembelajaran serta dapat memunculkan karakter yang dimiliki siswa dan meningkatkan kinerjanya dalam pembelajaran.

Pembelajaran dengan Model Problem Based Learning adalah suatu lingkungan belajar dimana masalah mengendalikan proses belajar mengajar. Hal ini berarti sebelum pelajar belajar, mereka diberikan umpan berupa masalah. Masalah diajukan agar pelajar mengetahui bahwa mereka harus mempelajari beberapa pengetahuan baru sebelum mereka memecahkan masalah tersebut. Model problem based learning ini digunakan untuk memecahkan masalah atau menemukan tantangan-tantangan yang dihadapi dalam hidup dan pekerjaan. Menurut sumantri (2015:47), model Problem Based Learning memiliki beberapa sintaks atau langkah-langkah yaitu 1) Guru menjelaskan tujuan pembelajaran, menjelaskan alat bahan yang dibutuhkan, mengajukan fenomena atau demonstrasi atau cerita untuk memunculkan masalah, memotivasi siswa untuk terlibat dalam pemecahan masalah yang dipilih, 2) Guru membantu siswa untuk mendefinisikan dan mengorganisasitugas belajar yang berhubungan dengan masalah tersebut, 3) Guru mendorong siswa untuk mengumpulkan informasi yang sesuai, melaksanakan elsperimen untuk mendapatkan penjelasan dan pemecahan masalah, 4) Guru membantu siswa dalam merencanakan dan menyiapkan karya yang sesuai dengan laporan, video, dan model serta membantu mereka untuk berbagi tugas dengan temannya, 5) Guru membantu siswa untuk melakukan refleksi atau 
evaluasi terhadap penyelidikan mereka dan proses - proses yang mereka gunakan. Di samping itu menurut Sumantri (2015:46), model Problem Based Learning memiliki beberapa kelebihan, diantaranya sebagai berikut. 1) Melatih siswa untuk mendesain suatu penemuan. 2) Berpikir dan bertindak kreatif. 3) Siswa dapat memecahkan masalah yang dihadapi secara realistis. 4) Mengindetifikasi dan mengevaluasi penyelidikan. 5) Menafsirkan dan mengevaluasi hasil pengamatan. 6) Merangsang bagi perkembangan kemajuan berpikir siswa untuk menyelesaikan suatu permasalahan yang dihadapi dengan tepat. 7) Dapat membuat pendidikan lebih relevan dengan kehidupan. Berbeda pada kelompok kontrol, kegiatan pembelajaran konvensional yang berjalan kurang optimal. Hal ini disebabkan pembelajaran konvensional masih sangat pasif dan monoton. Pembelajaran menggunakan model Problem Based Learning berbasis portofolio pada muatan Matematika memberikan kesempatan yang lebih luas kepada siswa untuk belajar melalui upaya penyelesaian permasalahan dunia nyata secara terstruktur untuk mengkonstruksikan pengetahuan siswa. Kegiatan pembelajaran pada kelompok kontrol dan kelompok eksperimen sama-sama menggunakan Kurikulum 2013 dimana pembelajarannya menggunakan pendekatan saintifik yang digunakan dalam proses pembelajaran sehari-hari. Perbedaan perlakuan yaitu pada kelompok eksperimen diberikan perlakuan dengan model Problem Based Learning berbasis portofolio, tetapi pada kelompok kontrol tidak diberikan perlakuan hanya menggunakan pembelajaran konvensional sehingga kompetensi pengetahuan Matematika pada kelompok kontrol kurang optimal dibandingkan dengan kelompok eksperimen. Dengan demikian, perbedaan hasil kompetensi pengetahuan Matematika dapat terlihat dari langkah pembelajaran yang dilakukan pada kedua kelompok tersebut, hasil analisis uji hipotesis, dan nilai rata-rata kelompok siswa yang mengikuti pembelajaran menggunakan model Problem Based Learning dengan siswa yang mengikuti pembelajaran konvensional.

Hasil penelitian ini memiliki kesan dengan penelitian yang dilakukan oleh Tnunay (2013) yang menyimpulkan bahwa ada perbedaan yang signifikan kemampuan menulis karya ilmiah antara mahasiswa yang mengikuti model pembelajaran berbasis masalah disertai asesmen portofolio dan mahasiswa yang mengikuti model pembelajaran konvensional. Demikian pula penelitian yang dilakaukan oleh Christina (2014) berdasarkan hasil uji hipotesis dan pembahasan hasil penelitian diketahui terdapat perbedaan yang signifikan kemampuan berpikir kritis IPA antara kelompok siswa yang dibelajarkan dengan model Problem Based Learning berbasis penilaian proyek dan yang dibelajarkan dengan pembelajaran konvensional pada kelas V Gugus VIII Kecamatan Sukawati tahun ajaran 2013/2014.

Berdasarkan paparan tersebut, dapat dikatakan bahwa model Problem Based Learning berbasis portofolio berpengaruh terhadap kompetensi pengetahuan Matematika siswa kelas IV SD Gugus I Gusti Ngurah Rai Tahun Pelajaran 2017/2018.

\section{KESIMPULAN}

Berdasarkan penjelasan diatas penelitian ini dapat disimpulkan sebagai berikut:

1. Berdasarkan hasil analisis data kompetensi pengetahuan matematika pada kelompok eksperimen terdapat 30 siswa dengan nilai tertinggi yang diperoleh 91,3 dan nilai terendah adalah 69,6. Dari sebaran data tersebut diperoleh data rata-rata (mean) adalah 78,50 yang berdasarkan PAP skala 5 termasuk kriteria cukup.

2. Berdasarkan hasil analisis data kompetensi pengetahuan matematika pada kelompok kontrol terdapat 30 siswa dengan nilai tertinggi yang diperoleh 91,3 dan nilai terendah adalah 56,5. Dari sebaran data tersebut diperoleh data rata-rata (mean) adalah 74,17 yang berdasarkan PAP skala 5 termasuk kriteria cukup.

3. Dari hasil analisis diperoleh $t_{\text {hitung }}=2,406$ dengan taraf signifikansi $5 \%$ dengan $\mathrm{dk}=\mathrm{n} 1+\mathrm{n} 2-2=$ $(30+30-2)=58$ maka diperoleh $t_{\text {tabel }}=2,000$. Oleh karena $t_{\text {hitung }}(2,406)>t_{\text {tabel }}(2,000)$ maka $\mathrm{H}_{0}$ ditolak. Hal ini membuktikan bahwa tidak terdapat perbedaan yang signifikan kompetensi pengetahuan matematika kelompok siswa yang dibelajarkan melalui model Problem Based Learning berbasis portofolio dengan kelompok dengan kelompok siswa yang dibelajarkan melalui pembelajaran konvensional pada kelas IV SD Gugus I Gusti Ngurah Rai tahun pelajaran 2017/2018.

Dilihat dari rata-rata kelompok siswa yang dibelajarkan melalui model Problem Based Learning berbasis portofolio $\bar{X}=78,50>\bar{X}=74,18$ kelompok siswa yang dibelajarkan dengan pembelajaran konvensional. Jadi dapat disimpulkan bahwa model Problem Based Learning berbasis portofolio berpengaruh terhadap kompetensi pengetahuan matematika Siswa Kelas IV SD Gugus I Gusti Ngurah Rai tahun pelajaran $2017 / 2018$. 
Saran yang dapat peneliti sampaikan dalam penelitian ini antara lain:

1. Kepada Guru

Berdasarkan simpulan penelitian yang diperoleh, disarankan kepada guru agar lebih kreatif untuk memberikan fasilitas berupa sumber belajar dan kesempatan yang lebih besar bagi siswa pada pembelajaran yang menggunakan model Problem Based Learning berbasis portofolio dan dapat dijadikan alternatif dalam proses pembelajaran untuk membantu peserta didik meningkatkan kompetensi pengetahuan matematika dengan maksimal.

2. Kepada Kepala Sekolah

Berdasarkan simpulan penelitian, disarankan kepada kepala sekolah agar dapat menggunakan hasil penelitian ini sebagai alternatif dalam mengelola pembelajaran agar sesuai dengan karakteristik pembelajaran matematika, sehingga mampu meningkatkan pengetahuan dan pemahaman peserta didik tentang matematika.

3. Kepada Peneliti Lain

Berdasarkan simpulan penelitian, disarankan kepada peneliti lain agar hasil penelitian ini digunakan sebagai suatu acuan bagi peneliti lain untuk mengembangkan kemampuan diri dalam mempersiapkan diri sebagai calon pendidik dan meningkatkan pemahaman mengenai kurikulum 2013 dengan penerapan model Problem Based Learning berbasis portofolio.

\section{DAFTAR PUSTAKA}

Kementrian Pendidikan dan Kebudayaan. 2014. Peraturan Menteri Pendidikan dan Kebudayaan Republik Indonesia Nomor 57 Tahun 2014. Jakarta: Kemendikbud.

Kementrian Pendidikan dan Kebudayaan. 2014. Peraturan Menteri Pendidikan dan Kebudayaan Republik Indonesia Nomor 103 Tahun 2014. Jakarta: Kemendikbud.

Kosasih. 2014. Strategi Belajar Dan Pembelajaran. Bandung: Yrama Widya.

Muslich, Masnur. 2011. KTSP (Kurikulum Tingkat Satuan Pendidikan) Dasar Pemahaman Dan Pengembangan . Jakarta: PT Bumi Aksara.

Munirah. 2015. Sistem Pendidikan Di Indonesia: Antara Keinginan Dan Realita . Jurnal Auladuna, Vol. 2 No. 2 Desember 2015: 233-245

Nafiah, Y. N. (2012). Penerapan Model Problem-Based Learning untuk Meningkatkan Keterampilan Berpikir Kritis dan Hasil Belajar Siswa. Jurnal Pendidikan Vokasi, 1(1).

Nurkholis. 2013. Pendidikan Dalam Upaya Memajukan Teknologi . Jurnal Kependidikan, Vol. 1 No. 1 Nopember 2013

Riadi, Muchlisin. 2013. Pengertian Model Pembelajaran Berbasis Portofolio. Bandung :https://www.kajianpustaka .com/2013/01/ model-pembelajaran- berbasis- portofolio.html?m=1 (diakses pada tanggal 28 januari 2018).

Sani, R.A. 2015. Pembelajaran Saintifik Untuk Implementasi Kurikulum 2013. Jakarta: Bumi Aksara.

Sanjaya, Wina. 2009. Kurikulum dan Pembelajaran. Jakarta: Prenada Media Group.

Sumantri. 2015. Strategi Pembelajaran Teori dan Praktek di Tingkat Pendidikan Dasar. Jakarta: PT. Raja Grafindo Persada.

Sumarji. 2009. Penerapan Model Pembelajaran Problem Based Learning untuk Meningkatkan Motivasi dan Kemampuan Pemecahan Masalah Ilmu Statika dan Tegangan di SMK. Jurnal Teknologi dan Kejuruan, Vol. 32(2), hal 129-140

Susanto, Ahmad. 2014. Teori Belajar \& Pembelajaran di Sekolah Dasar. Jakarta: Prenadamedia.

Suandito, Billy. 2017. Bukti Informal dalam Pembelajaran Matematika . Jurnal Pendidikan Matematika Vol. 8, No. 1, 2017

Swari, Putu Kartika Widya, I Made Agus Wirawan, I Made Gede Sunarya. 2015. Penerapan Model Pembelajaran Berbasis Masalah (Problem Based Learning) Berbantuan Jobsheet Untuk 
Meningkatkan Hasil Belajar Siswa Pada Mata Pelajaran Pemrograman Web Di Kelas X Tkj 4 Smk Negeri 3 Singaraja. Karmapati Volume 4, Nomor 3.

Wahyudi. 2015. Pengaruh Problem Based Learning Terhadap Keterampilan Proses Sains Dan Hasil Belajar BiologiSiswaKelas X SMA Negeri Jumapolo Tahun Pelajaran 2013/2014. Jurnal Bio-Pedagogi, Vol. 4 (1), hal 5-11

Widodo.2013. Peningkatan Aktivitas Belajar dan Hasil Belajar Siswa dengan Metode Problem Based Learning pada Siswa Kelas VIIA MTs Negeri Donomulyo Kulon Progo Tahun Pelajaran 2012/2013. Jurnal fisika indonesia, Vol. XVII (49), hal32-35

Wulandari, Bekti. 2013. Pengaruh Problem Based Learning Terhadap Hasil Belajar Ditinjau Dari Motivasi Belajar PLC Di SMK. Jurnal Pendidikan Vokasi, Vol 3(2), hal 178-19

Yanti, Ni Wayan Widya. 2014. Penerapan Model Pembelajaran Pbl Berbantuan Power Point Untuk Meningkatkan Hasil Belajar Pkn . Jurnal Jurusan Pendidikan Pancasila Dan Kewarganegaraan Fakultas Ilmu Sosial Universitas Pendidikan Ganesha Volume 3 Nomor 1. 